\title{
Respon tanaman mawar batik (Rosa hybrida L.) dengan penggunaan konsentrasi 1-methylcyclopropene (1-MCP) pada beberapa tingkat kemekaran bunga
}

\section{Response batik roses (Rosa Hybrida L.) with the use concentration of 1-methylcyclopropene (1-MCP) on some level of florescence}

Diterima : 15 September 2015/Disetujui : 15 Oktober 2015 / Dipublikasikan : Oktober 2015

CDepartment of Crop Science, Padjadjaran University

\begin{abstract}
Batik rose as an ornamental pot plant that has a good quality proportional canopy, similar flower size and long freshness of flowers, so the roses beauty can be enjoyed longer. This experimentaims to obtain florescence combinations and concentrations of 1-Methylcyclopropene (1$\mathrm{MCP}$ ) on the growth and quality of the batik rose flowers. This research was conducted in Kampung Cihideung's Greenhouse from January 2014 to February 2014. Treatments were arranged in split plot design consist of five concentrations of 1-MCP

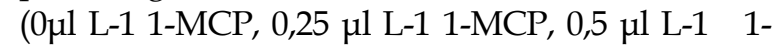
$\mathrm{MCP}, 0,75 \mu \mathrm{L}-1$ 1-MCP and $1 \mu \mathrm{l} \mathrm{L-1} 1-\mathrm{MCP})$ as sub plot and four scales of inflorescences as main plot $(0-10 \%, 10-25 \%, 50-75 \%$ and $100 \%)$. The result showed that 1-MCP affected diameter and freshness of batik rose flower, but don't showed significant response to plant height, number of branch, diameter of branch, number of leaves plant. Combination treatment $\mathrm{a}_{1} \mathrm{~m}_{3}$ (efflorescence 0-10\%, a dose of $0.5 \mu \mathrm{L}^{-1}$ ) and $\mathrm{a}_{3} \mathrm{~m}_{2}$ (efflorescence $50-75 \%$, a dose of $0.25 \mu \mathrm{L}^{-1}$ ) gives the best effect on the freshness of flowers with a long parameter value of each - every 9.83 days and 9.72 days. Combination treatment $\mathrm{a}_{1} \mathrm{~m}_{2}$ (efflorescence $0-10 \%$, a dose of $0.25 \mu \mathrm{L} \mathrm{L}^{-1}$ ) and $\mathrm{a}_{3} \mathrm{~m}_{2}$ (efflorescence 50$75 \%$, a dose of $0.25 \mu \mathrm{L}^{-1}$ ) have the value smaller than the other treatments with respective values respectively 0.67 and $0.61 \mathrm{~cm}$ in diameter increment parameter of interest.
\end{abstract}

Keywords : 1-Methylcyclopropene - Batik rose . Flowers quality

\footnotetext{
Dikomunikasikan oleh Y. Maxiselly

Suradinata Y.R. ${ }^{1}$. A. Wulansari ${ }^{2}$

${ }^{1}$ Dept. Budadaya Pertanian Fakultas Pertanian Unpad

2 Alumni Program Sarjana Agroteknologi Faperta Unpad

Korespondensi: dryayat_effendi@yahoo.com
}

Sari Mawar batik sebagai tanaman hias pot yang berkualitas baik memiliki tajuk yang proposional, ukuran bunga yang seragam dan memiliki kesegaran bunga yang lama, sehingga bunga mawar dapat dinikmati keindahannya lebih lama. Percobaan ini bertujuan untuk memperoleh kombinasi kemekaran bunga dan konsentrasi 1 Methylcyclopropene (1-MCP) terhadap pertumbuhan dan kualitas bunga pada tanaman mawar batik. Percobaan dilaksanakan sejak Januari 2014 hingga Februari 2014 di greenhouse yang berada di Desa Cihideung, Kabupaten Bandung Barat. Percobaan menggunakan Rancangan Petak Terbagi dengan dua factor, yaitu kemekaran bunga dan dosis 1-MCP, diulang sebanyak tiga kali. Kemekaran bunga yang digunakan yaitu kemekaran 0-10 \%, kemekaran 10-25 \%, kemekaran 50-75 \% dan kemekaran $100 \%$. Konsentrasi 1-MCP yang diaplikasikan yaitu, $0 \mu \mathrm{l}$ $\mathrm{l}^{-1} 1$-MCP, $0,25 \mu \mathrm{l} \mathrm{l}^{-1} 1$-MCP, $0,5 \mu \mathrm{l}^{-1} 1$ 1-MCP, $0,75 \mu \mathrm{l}$ $\mathrm{l}^{-1} 1-\mathrm{MCP}$ dan $1 \mathrm{\mu l} \mathrm{l}^{-1} 1-\mathrm{MCP}$. Perbedaan antar perlakuan diuji dengan menggunakan uji $\mathrm{F}$, sedangkan menguji perbedaan rata-rata perlakuan digunakan Uji Jarak Berganda Duncan pada taraf nyata $5 \%$. Hasil percobaan menunjukan bahwa kemekaran bunga dan konsentrasi 1-MCP berpengaruh terhadap komponen kualitas bunga yaitu, pertambahan diameter bunga dan lama kesegaran bunga, tapi tidak berpengaruh terhadap diameter bunga mekar. Sedangkan pada komponen pertumbuhan berupa pertambahan tinggi, pertambahan jumlah cabang, pertambahan diameter batang dan pertambahan daun per tanaman, pada berbagai perlakuan tidak berpengaruh nyata. Kombinasi perlakuan $\mathrm{a}_{1} \mathrm{~m}_{3}$ (kemekaran 0-10 \%, dosis 0,5 $\mathrm{\mu l} \mathrm{l}^{-1}$ ) dan $\mathrm{a}_{3} \mathrm{~m}_{2}$ (kemekaran 50-75\%, dosis 0,25 $\mathrm{ll}^{-1}$ ) memberikan pengaruh lebih baik terhadap parameter lama kesegaran bunga dengan nilai masing-masing 9,83 hari dan 9,72 hari. Kombinasi perlakuan $\mathrm{a}_{1} \mathrm{~m}_{2}$ 
(kemekaran 0-10 \%, dosis 0,25 $\mu \mathrm{ll}^{-1}$ ) dan $\mathrm{a}_{3} \mathrm{~m}_{2}$ (kemekaran $50-75 \%$, dosis $0,25 \mathrm{\mu l} \mathrm{l}^{-1}$ ) memiliki nilai yang lebih kecil dari perlakuan lain dengan nilai masing-masing 0,67 dan $0,61 \mathrm{~cm}$ pada parameter pertambahan diameter bunga.

Kata kunci : 1 - Methylcyclopropene $\cdot$ Kualitas bunga $\cdot$ Mawar batik

\section{Pendahuluan}

Mawar atau Rosa hybrida termasuk ke dalam famili Rosaceae. Tanaman ini termasuk salah satu komoditas tanaman hias yang banyak dibudidayakan dan diusahakan di Indonesia karena memiliki nilai ekonomi yang tinggi. Berdasarkan kegunaannya, tanaman mawar sering digunakan sebagai tanaman hias pot, bunga potong, dan dapat digunakan sebagai tanaman penghias taman, selain itu mawar juga digunakan sebagai bunga tabur (rampai) dan bahan industri kosmetik dan pewangi (Suryowinoto, 1997).

Tanaman hias pot berkualitas baik memiliki tajuk yang proposional, ukuran bunga yang seragam dan memiliki kesegaran bunga yang lama. Mawar pot memiliki kesegaran bunga lebih lama dibandingkan dengan mawar potong yang hanya bisa bertahan 3-5 hari saja. Setelah bunga layu, mawar pot masih dapat dinikmati keindahannya namun tanaman tetap dirawat dengan baik sehingga mawar pot dapat berbunga kembali. Berbeda dengan mawar potong yang setelah layu bunganya lalu dibuang.

Mawar dapat ditanam di lapangan maupun di rumah kaca. Cahaya, suhu dan karbon dioksida merupakan faktor yang perlu diperhatikan untuk mawar yang ditanam di rumah kaca,karena cahaya, suhu dan karbon dioksida merupakan faktor yang mempengaruhi pertumbuhan dan perkembangan mawar yang tumbuh di dalam greenhouse (Dole and Wilkins, 2005). Selain faktor lingkungan, media tanam dan ketersediaan hara serta air juga berpengaruh terhadap pertumbuhan tanaman mawar.

Salah satu tanaman hias pot yang banyak diminati konsumen adalah mawar batik. Mawar batik merupakan hasil persilangan mawar lokal dan mawar impor. Misalnya persilangan antara mawar merah dengan mawar merah tua yang nyaris hitam sekaligus juga mawar putih, hasilnya akan memperlihatkan sekuntum mawar dengan warna yang penuh motif (Arifin, 2009). Sebagai tanaman pot, yang dinikmati konsumen pada mawar batik adalah keindahan bunganya. Semakin lama bunga tersebut mekar, maka semakin lama pula konsumen dapat menikmati keindahan tanaman ini.

Salah satu faktor yang menyebabkan kelayuan pada bunga adalah karena adanya hormon etilen. Etilen merupakan hormon tanaman yang mempunyai efek merangsang proses kematangan buah, serta berpengaruh dalam mempercepat terjadinya senesen pada sayur, bunga potong dan tanaman hias lain. Pengaruh etilen pada tanaman hias yaitu, terjadinya gugur pada daun, kuncup bunga, kelopak bunga, atau secara umum terjadi pada daerah sambungan atau sendi tanaman (Setyadjit dkk., 2012).

Berbagai usaha telah dilakukan untuk mengurangi efek etilen secara kimiawi pada proses pemasakan dan senesen dengan cara aplikasi aminoethoxyvinylglycine (AVG) sebagai penghambat sintensis etilen, ion perak $\left(\mathrm{Ag}^{+}\right), 2,5-$ norbornadiene (NBD), diazocyclopentadiene (DACP) dan 1-methylcyclopropene (1-MCP) sebagai penghambat aksi etilen dengan menonaktifkan penerima (receptor) etilen (Sisler and Serek, 1999).

Dosis senyawa 1-MCP yang diperlukan pada berbagai jenis bunga, buah seperti buah tomat dan sayuran cukup dengan nano liter per liter (nL/L) (Setyadjit dkk,. 2012). Salah satu contoh pengaruh yang sangat efektif dalam penggunaan senyawa 1-MCP adalah pada bunga asli dari Australia yakni Grevillea 'Sylvia', dimana pada bunga ini efektifitas 1-MCP cukup dengan konsentrasi nL/L (Setyadjit et al., 2011).

Efektivitas 1-MCP dalam mencegah efek etilen tergantung dari jenis tanaman yang diberi 1-MCP, konsentrasi, durasi waktu pemberian, suhu, stadia pertumbuhan tanaman dan kedewasaan tanaman (Blankenship and Dole 2002; Dole and Wilkins 2005). Tahap perkem-bangan tanaman harus dipertimbangkan ketika menerapkan 1-MCP. Tingkat kemekaran pada bunga sangat mempengaruhi keberhasilan dari aplikasi senyawa $1-\mathrm{MCP}$, karena semakin mekar bunga maka semakin banyak 1-MCP yang dibutuhkan untuk menekan pengaruh buruk dari etilen (Setyadjit dkk., 2012)

\section{Bahan dan Metode}

Percobaan dilakukan dirumah plastik yang berada di desa Cihideung Kabupaten Bandung Barat, dengan ketinggian tempat $800 \mathrm{mdpl}$, suhu harian berkisar antara $17-24{ }^{\circ} \mathrm{C}$ dan curah hujan 
$2500 \mathrm{~mm} / \mathrm{th}$. Percobaan dilaksanakan dari bulan Januari hingga bulan Februari 2014.

Bahan yang digunakan dalam percobaan ini adalah mawar batik pada fase generatif awal yang ditandai dengan adanya bakal bunga. Tanaman mawar yang digunakan memiliki tinggi tanaman sekitar $25 \mathrm{~cm}$ dengan media tanam berupa sekam : pupuk kandang sapi (1:1), media tanam dimasukkan kedalam plastik polibag ukuran 30 (diameter $30 \mathrm{~cm}$ dan tinggi $25 \mathrm{~cm}$ ). Inhibitor etilen berupa ethylblock yang memiliki bahan aktif 1methylcyclopropene (1-MCP) sebesar 0,014 \%. Alatalat yang digunakan yaitu sungkup kedap udara yang dibuat dari plastik ultra violet (UV), jangka sorong, label, wadah plastik, alat tulis, kamera, timbangan analitik, gelas ukur dan alat - alat untuk bercocok tanam. Rancangan percobaan yang digunakan adalah Rancangan Petak Terbagi (Split Plot Design). Percobaan ini terdiri dari dua faktor dan tiga ulangan. Faktor pertama sebagai main plot berupa waktu aplikasi 1-MCP (A), faktor kedua sebagai sub plot yaitu konsentrasi 1-MCP (M).

Faktor pertama (main plot), waktu aplikasi 1MCP (A) terdiri dari empat taraf, yaitu :

$\mathrm{a}_{1}$ : Bunga mekar $0-10 \%$

$\mathrm{a}_{2}$ : Bunga mekar $10-25 \%$

$a_{3}$ : Bunga mekar $50-75 \%$;

$\mathrm{a}_{4}$ : Bunga mekar penuh (100\%)

Faktor kedua (Sub Plot), konsentrasi 1-MCP (M) terdiri dari lima taraf, yaitu :

$\mathrm{m}_{1}: 0 \mu \mathrm{LL}^{-1} 1-\mathrm{MCP}$

$\mathrm{m}_{2}: 0,25 \mu \mathrm{LL}^{-1} 1-\mathrm{MCP}$

$\mathrm{m}_{3}: 0,5 \mu \mathrm{LL}^{-1} 1-\mathrm{MCP}$

$\mathrm{m}_{4}: 0,75 \mu \mathrm{LL}^{-1} 1-\mathrm{MCP}$

$\mathrm{m}_{5}: 1 \mu \mathrm{LL}^{-1} 1-\mathrm{MCP}$
Terdapat 20 perlakuan dengan masingmasing diulang sebanyak tiga kali sehingga terdapat 60 unit percobaan. Setiap unit perco-baan terdiri dari 3 sampel tanaman, terdapat total populasi sebanyak 180 tanaman. Uji statistik yang digunakan untuk mengetahui pengaruh perlakuan dengan uji $\mathrm{F}$ pada taraf $5 \%$. Selanjutnya apabila ada pengaruh nyata, untuk menguji perbedaan nilai rata-rata perlakuan digunakan Uji Jarak Berganda Duncan pada taraf nyata $5 \%$.

\section{Hasil dan Pembahasan}

Berdasarkan hasil analisis data terhadap semua komponen pertumbuhan, menunjukan tidak terjadi interaksi antara faktor kemekaran bunga dengan konsentrasi 1-MCP.

Berdasarkan Tabel 1 pada parameter pertambahan jumlah cabang, perlakuan $a_{1}$ (kemekaran 0-10 \%) berbeda nyata bila dibandingkan dengan perlakuan a4 (kemekaran $100 \%$ ) tapi tidak berbeda nyata bila dibandingkan dengan perlakuan $\mathrm{a}_{2}$ (kemekaran 10-25\%) dan a3 (kemekaran 50-75 \%). Perlakuan a4 (kemekaran $100 \%)$ memberikan pengaruh yang rendah diduga karena pada tingkat kemekaran $a_{4}$ (kemekaran $100 \%$ ) tanaman menyuplai hara dan hasil fotosintesis untuk perkembangan bunga, sehingga menyebabkan pertumbuhan cabang menjadi rendah. Hal ini sejalan dengan Franklin dkk., (1991), yang menyatakan jika pada awal fase reproduktif organ-organ vegetatif gagal bersaing dengan organ reproduktif untuk mendapatkan hasil asimilat. Perlakuan kemekaran bunga dan

Tabel 1. Pengaruh Tingkat Kemekaran Bunga dan 1-Methylcyclopropene(1-MCP) terhadap Komponen Pertumbuhan Mawar.

\begin{tabular}{ccccc}
\hline Perlakuan & $\begin{array}{c}\text { Pertambahan Tinggi } \\
\text { Tanaman }(\mathbf{c m})\end{array}$ & $\begin{array}{c}\text { Pertambahan Jumlah } \\
\text { cabang }\end{array}$ & $\begin{array}{c}\text { Pertambahan Diameter } \\
\text { Batang }(\mathbf{c m})\end{array}$ & $\begin{array}{c}\text { Pertambahan Daun } \\
\text { Per-tanaman }\end{array}$ \\
\hline Kemekaran Bunga & $9,71 \mathrm{a}$ & $0,98 \mathrm{~b}$ & $0,31 \mathrm{~b}$ & $1,22 \mathrm{a}$ \\
$\mathrm{a}_{1}$ & $8,50 \mathrm{a}$ & $0,73 \mathrm{ab}$ & $0,19 \mathrm{a}$ & $1,29 \mathrm{a}$ \\
$\mathrm{a}_{2}$ & $9,33 \mathrm{a}$ & $1,06 \mathrm{~b}$ & $0,21 \mathrm{a}$ & $1,29 \mathrm{a}$ \\
$\mathrm{a}_{3}$ & $7,81 \mathrm{a}$ & $0,60 \mathrm{a}$ & $0,20 \mathrm{a}$ & $1,26 \mathrm{a}$ \\
$\mathrm{a}_{4}$ & & & & $1,28 \mathrm{a}$ \\
\hline Konsentasi 1-MCP & $8,71 \mathrm{a}$ & $0,75 \mathrm{a}$ & $0,24 \mathrm{a}$ & $1,08 \mathrm{a}$ \\
$\mathrm{m}_{1}$ & $9,09 \mathrm{a}$ & $0,83 \mathrm{a}$ & $0,22 \mathrm{a}$ & $1,58 \mathrm{a}$ \\
$\mathrm{m}_{2}$ & $8,49 \mathrm{a}$ & $1,05 \mathrm{a}$ & $0,23 \mathrm{a}$ & $1,11 \mathrm{a}$ \\
$\mathrm{m}_{3}$ & $9,20 \mathrm{a}$ & $0,77 \mathrm{a}$ & $0,22 \mathrm{a}$ & $1,28 \mathrm{a}$ \\
$\mathrm{m}_{4}$ & $8,68 \mathrm{a}$ & $0,80 \mathrm{a}$ & $0,24 \mathrm{a}$ & \\
$\mathrm{m}_{5}$ & & & & \\
\hline \hline
\end{tabular}

Keterangan : Angka rata- rata dalam tiap kolom yang ditandai oleh huruf yang sama tidak berbeda nyata pada taraf $5 \%$ menurut Uji Jarak Berganda Duncan. 
konsentrasi 1-MCP yang tidak memberikan pengaruh diduga karena pertumbuhan tinggi tanaman, diameter batang dan jumlah daun per tanaman dipengaruhi oleh lingkungan tumbuh tanaman yang berada di dalam greenhouse.Salah satu faktor lingkungan yang berpengaruh terhadap pertumbuhan dan perkembangan tanaman adalah suhu. Waktu siang hari merupakan suhu optimum tanaman berfotosintesis dan melakukan respirasi, sedangkan di malam hari tanaman melakukan respirasi dengan laju yang lebih lambat pada suhu yang lebih rendah. Menurut Widiastoety (1995), suhu yang terlalu tinggi akan meningkatkan respirasi dan merombak sebagian besar hasil fotosintesis yang menyebabkan cadangan makanan berkurang sehingga pertumbuhan tanaman terham- bat. Hal ini diperkuat oleh Parker (1999), yang menyatakan pertumbuhan tanaman dapat terjadi jika laju fotosintesis lebih besar dari laju respirasi.

Grafik pada Gambar 1 menunjukan perlakuan 1-MCP pada berbagai konsentrasi tidak berpengaruh terhadap pertambahan tinggi tanaman, hal ini diduga karena pertambahan tinggi tanaman dipengaruhi oleh faktor lingkungan. Benyamin (1996), menyatakan bahwa laju pemanjangan batang berbeda antar spesies dan dipengaruhi oleh lingkungan dimana tanaman tersebut tumbuh. Faktor lingkungan yang besar pengaruhnya terhadap pemanjangan batang adalah suhu dan intensitas cahaya, dimana laju pemanjangan batang berbanding terbalik dengan intensitas cahaya.

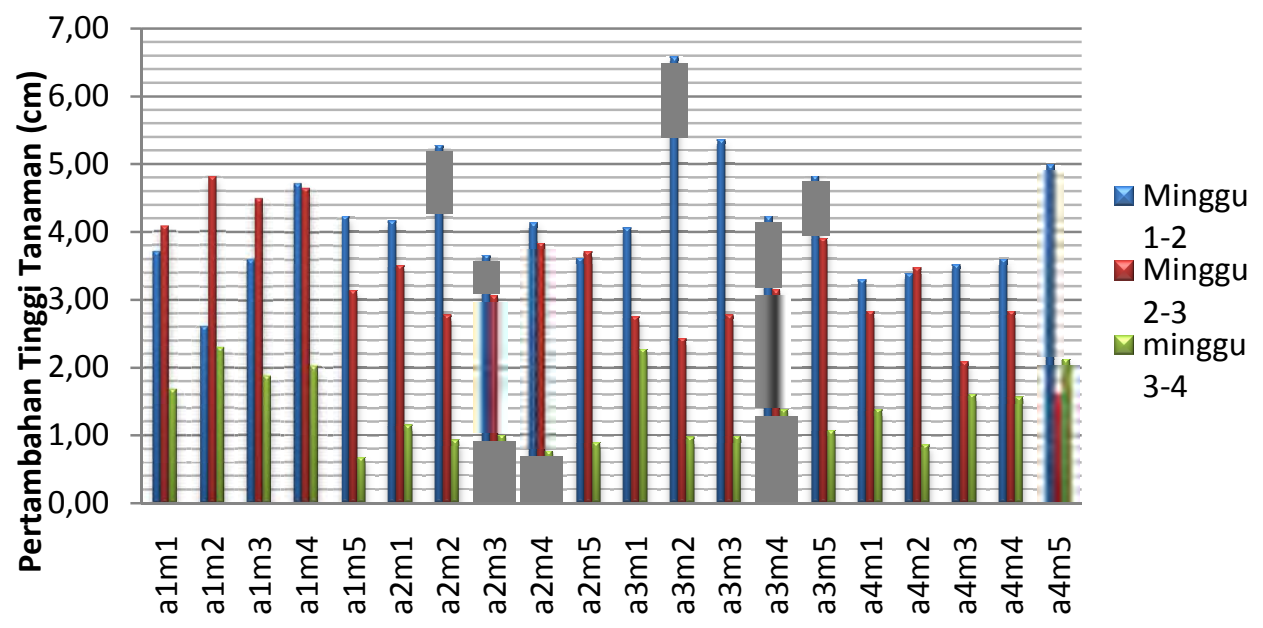

Perlakuan

Gambar 1. Grafik Pertambahan Tinggi Tanaman pada Minggu 1-2 Hingga Minggu 3-4 Setelah Tanaman Dipindahkan ke Dalam Plot-plot Percobaan.

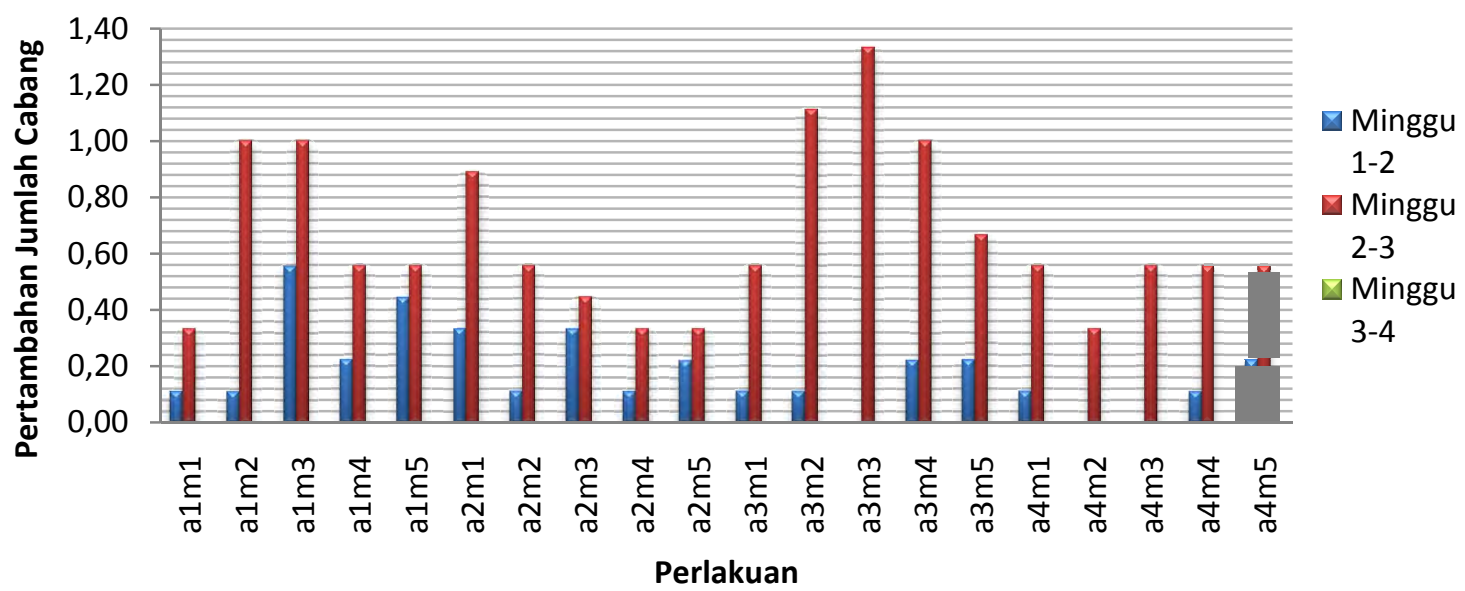

Gambar 2. Grafik Pertambahan Jumlah Cabang pada Minggu 1-2 Hingga Minggu 3-4 Setelah Tanaman Dipindahkan ke dalam Plot-plot Percobaan. 


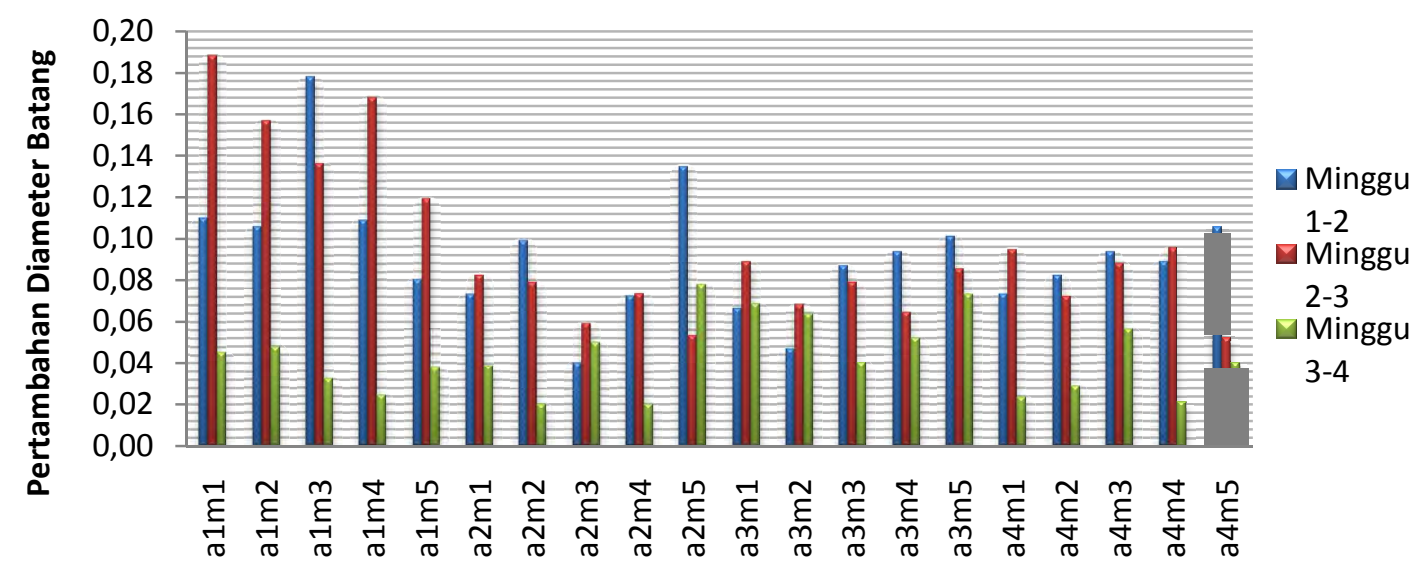

Perlakuan

Gambar 3. Grafik Pertambahan Diameter Batang pada Minggu 1-2 Hingga Minggu 3-4 Setelah Tanaman Dipindahkan ke dalam Plot-plot Percobaan.

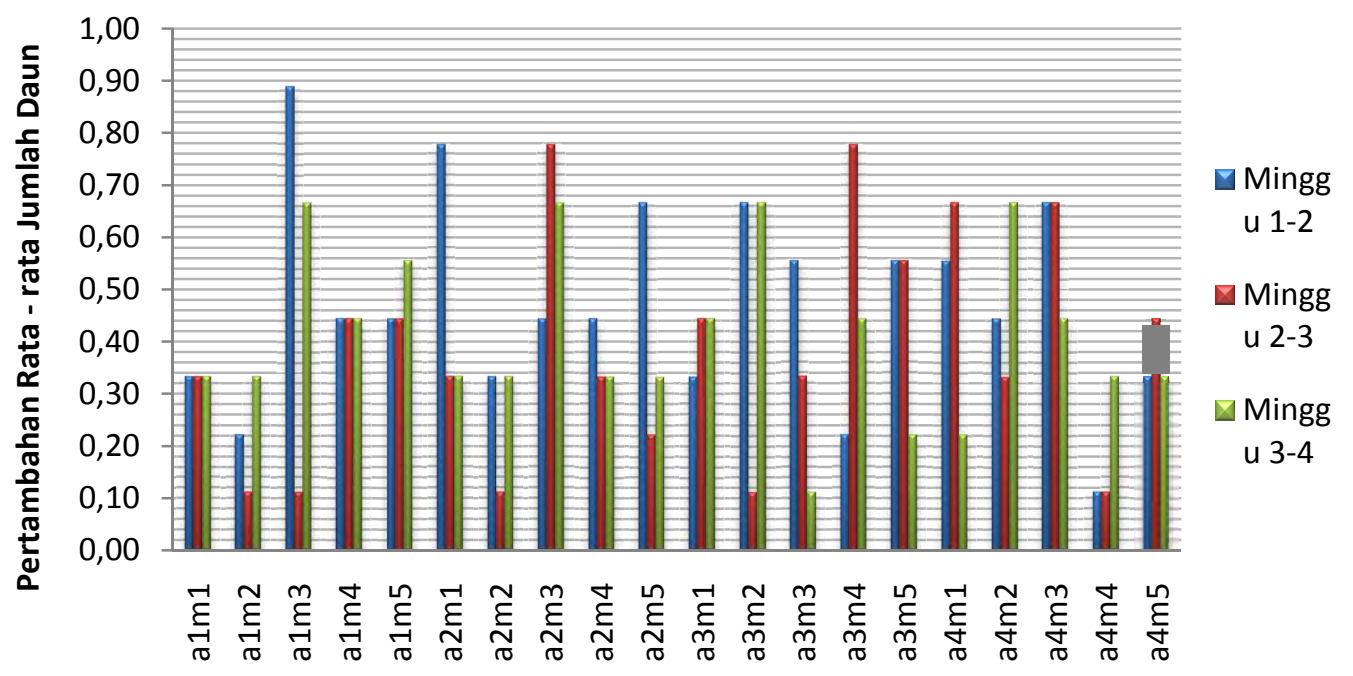

Perlakuan

\section{Gambar 4. Grafik Rata-rata Pertambahan Daun Per Tanaman pada Minggu 1-2 Hingga Minggu 3-4 Setelah Tanaman Dipindahkan ke dalam Plot-plot Percobaan.}

Pertambahan jumlah cabang yang tinggi di minggu ke 2-3 tetapi terhenti di minggu 3-4 diduga karena arah pertumbuhan tanaman sudah tertuju ke organ generatif, sehingga pertambahan jumlah cabang terhenti karena tanaman menyalurkan fotosintat dan hara pada organ generatif. Hal ini sejalan dengan Salisbury dan Ross (1995), yang menyatakan jika perkembangan bunga dan buah menyebabkan timbulnya persaingan hara. Perkembangan fase reproduktif yang menyebabkan pengalihan hara menuju bunga dan buah, sehingga memperlambat pertumbuhan vegetatif.

Gambar 3 menunjukkan pemberian konsentrasi 1-MCP nampaknya memberikan efek pada pertambahan diameter batang. Pada grafik menunjukan jika nilai pertambahan diameter batang tertinggi terjadi pada perlakuan $\mathrm{a}_{1} \mathrm{~m}_{1}$ (kemekaran 0-10\%, konsentrasi $0 \mu \mathrm{L} \mathrm{L}^{-1}$ ) yang merupakan kontrol dengan nilai rata-rata pertambahan diameter batang selama percobaan sebesar 0,11 cm, sedangkan perlakuan $\mathrm{a}_{2} \mathrm{~m}_{3}$ (kemekaran 10-25 \%, konsentrasi 0,5 $\mu \mathrm{L} \mathrm{L}^{-1}$ ) memiliki pertambahan diameter batang terendah dengan nilai $0,05 \mathrm{~cm}$ selama percobaan berlangsung. Hal ini diduga karena perlakuan $\mathrm{a}_{1} \mathrm{~m}_{1}$ (kemekaran 0-10\%, konsentrasi $0 \mu \mathrm{L} \mathrm{L} \mathrm{L}^{-1}$ ) menyebabkan etilen tidak terhambat oleh 1$\mathrm{MCP}$, sehingga etilen menyebabkan terhambatnya pemanjangan batang tapi justru menambah pertumbuhan diameter batang. Hal ini sejalan dengan Salisbury dan Ross (1995), yang 
menyatakan bahwa etilen menghambat pemanjangan batang dan akar, bila pemanjangan terhambat maka batang dan akar menjadi lebih tebal.

Gambar 4 selain dipengaruhi oleh pemberian pupuk, pertambahan jumlah daun juga dipengaruhi oleh faktor genetik dan lingkungan tumbuh. Sejalan dengan Humphries dan Wheeler (1963) yang menyatakan jika jumlah dan ukuran daun dipengaruhi oleh genotipe dan lingkungan.

Faktor lingkungan yang mempengaruhi pertumbuhan dan perkembangan daun antara lain intensitas cahaya, suhu, ketersediaan air dan unsur hara. Berat dan volume daun akan lebih tinggi pada intensitas cahaya yang tinggi, tetapi luas daun akan lebih tinggi bila tanaman tumbuh pada intensitas cahaya rendah (Benyamin, 1996).

\section{Komponen Kualitas Bunga}

Diameter Bunga Mekar. Berdasarkan hasil analisis statistik menunjukan bahwa tidak terjadi interaksi antara berbagai kemekaran bunga dengan konsentrasi 1-MCP terhadap diameter bunga mekar.

Tabel 2.Pengaruh Tingkat Kemekaran Bunga dan 1-Methylcyclopropene (1-MCP) terhadap Diameter Bunga Mekar (cm).

\begin{tabular}{cc}
\hline \hline \multicolumn{1}{c}{ Perlakuan } & Diameter Bunga Mekar \\
\hline Kemekaran Bunga & 7,85 \\
$\mathrm{a}_{1}$ & 7,78 \\
$\mathrm{a}_{2}$ & 7,68 \\
$\mathrm{a}_{3}$ & 7,83 \\
$\mathrm{a}_{4}$ & \\
\hline Konsentrasi 1-MCP & 7,85 \\
$\mathrm{~m}_{1}$ & 7,76 \\
$\mathrm{~m}_{2}$ & 7,75 \\
$\mathrm{~m}_{3}$ & 7,76 \\
$\mathrm{~m}_{4}$ & 7,80 \\
$\mathrm{~m}_{5}$ & \\
\hline \hline
\end{tabular}

Tabel 2 menunjukan bahwa semua perlakuan kemekaran bunga dan konsentrasi 1-MCP tidak berpengaruh nyata terhadap diameter bunga mekar. Hal ini diduga karena diameter bunga mekar tidak dipengaruhi oleh 1MCP akan tetapi diameter bunga mekar dipengaruhi oleh faktor genetik tanaman.

Menurut Darliah dkk (1994), diameter bunga mawar dibagi menjadi tiga kelompok yaitu diameter bunga besar dengan ukuran lebih dari 9,5 cm, diameter bunga sedang dengan ukuran $8,0 \mathrm{~cm}$ sampai $9,5 \mathrm{~cm}$ dan diameter bunga kecil dengan ukuran lebih kecil dari 8,0 $\mathrm{cm}$. Rata-rata diameter bunga mekar pada percobaan kali ini adalah sebesar 7,77 cm yang termasuk kedalam kategori diameter bunga kecil.

Pertambahan Diameter Bunga. Berdasarkan hasil analisis statistik menunjukan bahwa terjadi interaksi antara berbagai kemekaran bunga dengan konsentrasi 1-MCP terhadap pertambahan diameter bunga.

Tabel 3. Pengaruh Tingkat Kemekaran Bunga dan 1-Methylcyclopropene(1-MCP)terhadap Pertambahan Diameter Bunga (cm/hari) Selama 3 Minggu Sejak Tanaman Dipindahkandalam Plot Percobaan.

\begin{tabular}{cccccc}
\hline \hline Perlakuan & \multicolumn{5}{c}{$\begin{array}{c}\text { Konsentrasi 1-MCP } \\
\text { terhadap Pertambahan Diameter } \\
\text { Bunga (cm/hari) }\end{array}$} \\
\hline $\begin{array}{c}\text { Kemekaran } \\
\text { Bunga }\end{array}$ & $\mathrm{m}_{1}$ & $\mathrm{~m}_{2}$ & $\mathrm{~m}_{3}$ & $\mathrm{~m}_{4}$ & $\mathrm{~m}_{5}$ \\
\hline $\mathrm{a}_{1}$ & $0,74 \mathrm{~A}$ & $0,67 \mathrm{AB}$ & $0,70 \mathrm{~A}$ & $0,84 \mathrm{~A}$ & $0,84 \mathrm{~A}$ \\
& $\mathrm{ab}$ & $\mathrm{a}$ & $\mathrm{a}$ & $\mathrm{b}$ & $\mathrm{b}$ \\
$\mathrm{a}_{2}$ & $0,82 \mathrm{~A}$ & $0,80 \mathrm{BC}$ & $0,77 \mathrm{~A}$ & $0,89 \mathrm{~A}$ & $0,83 \mathrm{~A}$ \\
& $\mathrm{a}$ & $\mathrm{a}$ & $\mathrm{a}$ & $\mathrm{a}$ & $\mathrm{a}$ \\
$\mathrm{a}_{3}$ & $0,81 \mathrm{~A}$ & $0,61 \mathrm{~A}$ & $0,91 \mathrm{~B}$ & $0,93 \mathrm{~A}$ & $0,90 \mathrm{~A}$ \\
& $\mathrm{~b}$ & $\mathrm{a}$ & $\mathrm{b}$ & $\mathrm{b}$ & $\mathrm{b}$ \\
$\mathrm{a}_{4}$ & $0,82 \mathrm{~A}$ & $0,91 \mathrm{C}$ & $0,77 \mathrm{~A}$ & $0,99 \mathrm{~A}$ & $0,93 \mathrm{~A}$ \\
& $\mathrm{ab}$ & $\mathrm{bc}$ & $\mathrm{a}$ & $\mathrm{c}$ & $\mathrm{bc}$ \\
\hline \hline
\end{tabular}

Keterangan : Angka-angka yang diikuti oleh huruf yang sama tidak berbeda nyata pada taraf nyata $5 \%$ menurut Uji Jarak Berganda DuncanHuruf kecil dibaca horizontal dan huruf besar dibaca vertikal.

Tabel 3 menunjukan nilai pertambahan diameter bunga yang tinggi didapat pada perlakuan a $(100 \%)$, hal ini diduga karena pertambahan diameter bunga yang lebih besar disebabkan oleh hormon etilen yang tidak dihambat oleh 1-MCP sehingga menyebabkan tingginya pertambahan diameter pada bunga. Semakin besar nilai pertambahan diameter bunga, menyebabkan bunga akan lebih cepat mekar. Sejalan dengan Winarno dan Aman (1981), yang menyatakan etilen dapat mempercepat proses pemekaran kuncup, akan tetapi kuncup yang telah mekar akan cepat mengalami kelayuan. Selama fase reproduktif, bunga akan mengalami perkembangan kuncup bunga menuju anthesis (bunga mekar). Akibatnya semakin tinggi tingkat kemekaran bunga, maka diameter bunga akan semakin besar.

Lama Kesegaran Bunga. Berdasarkan hasil analisis statistik menunjukan bahwa terjadi interaksi antara berbagai kemekaran bunga dengan konsentrasi 1-MCP terhadap lama kesegaran bunga. 

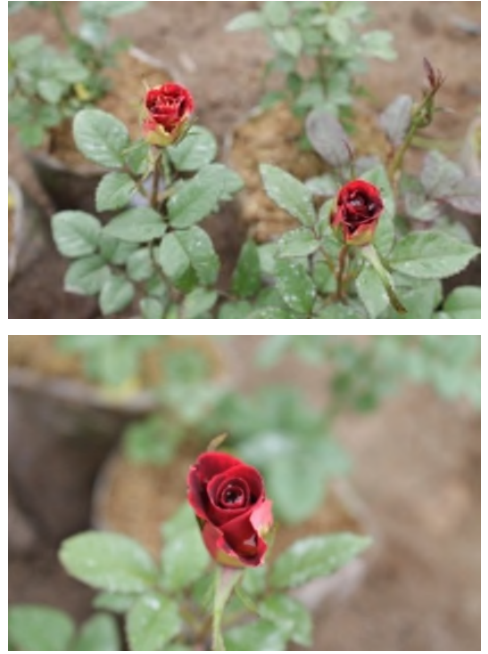

Gambar 5. Kiteria Kemekaran Bunga 0 - $10 \%$.
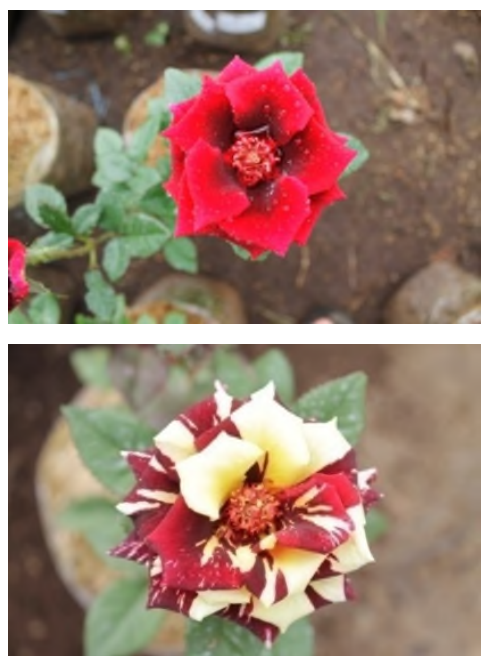

Gambar 6: Kiteria Kemekaran Bunga 100 \%.

Hasil analisis dapat disimpulkan jika pertambahan diameter bunga berbanding terbalik dengan lama kesegaran bunga. Semakin tinggi pertambahan diameter bunga, maka kesegaran bunga akan semakin berkurang, sedangkan semakin kecil pertambahan diameter bunga maka kesegaran bunga akan semakin lama. Penggunaan 1-MCP diharapkan dapat memperkecil nilai pertambahan bunga, sehingga bunga dapat mekar lebih lama, namun penggunaan 1-MCP dengan konsentrasi yang tinggi dan kemekaran bunga paling tinggi tidak memberikan efek yang nyata untuk memperpanjang lama kesegaran bunga. Hal ini sejalan dengan Blankenship dkk (2002) penggunaan 1MCP untuk memperpanjang lama kesegaran bunga dipengaruhi oleh berbagai faktor, salah satunya adalah tahap perkembangan dan kematangan tanaman. Tanaman pada tahap perkembangan harus dipertimbangkan ketika menerapkan 1-MCP sebagai efek yang bervariasi dengankematangan tanaman. Menurut Setyadjit dkk (2012) tingkat kemekaran sangat menentukan, karena semakin mekar suatu bunga maka bunga tersebut akan semakin cepat mengalami senesen sehingga pemberian 1-MCP tidak akan berpengaruh.

Tabel 4. Pengaruh Tingkat Kemekaran Bunga dan 1-Methylcyclopropen(1-MCP) terhadap Lama Kesegaran Bunga (hari) Selama 3 Minggu Sejak Tanaman Dipindahkan ke dalam Plot Percobaan.

\begin{tabular}{cccccc}
\hline \hline Perlakuan & \multicolumn{5}{c}{$\begin{array}{c}\text { Konsentrasi 1-MCP terhadap Lama } \\
\text { Kesegaran Bunga (hari) }\end{array}$} \\
\cline { 2 - 3 } $\begin{array}{c}\text { Kemekaran } \\
\text { Bunga }\end{array}$ & $\mathrm{m}_{1}$ & $\mathrm{~m}_{2}$ & $\mathrm{~m}_{3}$ & $\mathrm{~m}_{4}$ & $\mathrm{~m}_{5}$ \\
\hline $\mathrm{a}_{1}$ & $9,11 \mathrm{~B}$ & $8,95 \mathrm{~B}$ & $9,83 \mathrm{C}$ & $8,53 \mathrm{~B}$ & $7,78 \mathrm{~A}$ \\
& $\mathrm{ab}$ & $\mathrm{ab}$ & $\mathrm{b}$ & $\mathrm{ab}$ & $\mathrm{a}$ \\
$\mathrm{a}_{2}$ & $8,28 \mathrm{AB}$ & $8,56 \mathrm{~B}$ & $9,39 \mathrm{BC}$ & $8,09 \mathrm{~B}$ & $7,83 \mathrm{~A}$ \\
& $\mathrm{ab}$ & $\mathrm{ab}$ & $\mathrm{b}$ & $\mathrm{ab}$ & $\mathrm{a}$ \\
$\mathrm{a}_{3}$ & $7,39 \mathrm{~A}$ & $9,72 \mathrm{~B}$ & $7,06 \mathrm{~A}$ & $6,06 \mathrm{~A}$ & $6,17 \mathrm{~A}$ \\
& $\mathrm{~b}$ & $\mathrm{C}$ & $\mathrm{ab}$ & $\mathrm{a}$ & $\mathrm{a}$ \\
$\mathrm{a}_{4}$ & $8,06 \mathrm{AB}$ & $6,22 \mathrm{~A}$ & $8,17 \mathrm{AB}$ & $6,11 \mathrm{~A}$ & $6,06 \mathrm{~A}$ \\
& $\mathrm{~b}$ & $\mathrm{a}$ & $\mathrm{b}$ & $\mathrm{A}$ & $\mathrm{a}$ \\
\hline \hline
\end{tabular}

Keterangan : Angka-angka yang diikuti oleh huruf yang sama tidak berbeda nyata pada taraf nyata 5\% menurut Uji Jarak Berganda Duncan.Huruf kecil dibaca horizontal dan huruf besar dibaca vertikal.

\section{Kesimpulan dan Saran}

\section{Kesimpulan}

Berdasarkan hasil penelitian, maka dapat diperoleh kesimpulan sebagai berikut :

1. Konsentrasi 1-Methylcyclopropene (1-MCP) dan kemekaran bunga menunjukan adanya interaksi terhadap komponen kualitas bunga yaitu, lama kesegaran bunga dan pertambahan diameter bunga.

2. Aplikasi 1-Methycyclopropene (1-MCP) tidak berpengaruh nyata terhadap semua komponen pertumbuhan tanaman mawar, tetapi berpengaruh nyata terhadap kompo-nen kualitas bunga yaitu pada pertambahan diameter bunga dan lama kesegaran bunga, sedangkan pada diameter bunga mekar tidak ada pengaruh.

3. Kombinasi perlakuan konsentrasi 1-MCP dan kemekaran bunga pada perlakuan kemekaran 0-10 \% dengan konsentrasi 0,5 $\mu \mathrm{l}$ $\mathrm{L}^{-1}$ dan perlakuan kemekaran 50-75\% dengan konsentrasi $0,25 \mu 1 \mathrm{~L}^{-1}$ yang memiliki nilai masing-masing 9,83 hari dan 9,72 hari untuk parameter lama kesegaran bunga. 
Kombinasi perlakuan kemekaran 0-10 \% dengan konsentrasi $0,5 \mu \mathrm{L}^{-1}$ dan perlakuan kemekaran 50-75 \% dengan konsentrasi 0,25 Saran $\mu \mathrm{L}^{-1}$ dan memberikan pengaruh terbaik.

1. Menggunakan tanaman mawar batik yang memiliki kemekaran bunga 10 - 20\%. Pada kemekaran tersebut bunga mulai terlihat coraknya, sehingga tanaman yang digunakan untuk penelitian akan seragam warna dan coraknya.

2. Kondisi lingkungan tumbuh di dalam greenhouse yang memiliki suhu tinggi dan intensitas cahaya rendah mempengaruhi fotosintesis dan respirasi pada tanaman, sehingga disarankan untuk modifikasi lingkungan greenhouse agar sesuai dengan kondisi lingkungan yang dibutuhkan tanaman.

\section{Ucapan Terima Kasih}

Ucapan terima kasih saya berikan kepada Bapak Wawan Sutari dan semua pihak yang terlibat.

\section{Daftar Pustaka}

Arifin, Z. 2009. Mawar candy bisa bertahan sampai 15 hari. Surabaya Post. Malang Raya. Available at : (http://malangraya. web.id/2009/09/01/mawar-candy-bisabertahansampai15-hari/) Diakses pada 21 oktober 2013.

Benyamin L. 1996. Fisiologi Pertumbuhan dan Perkembangan Tanaman. PT. Grafindo Persada. Jakarta.

Blankenship S. and J. M. Dole. 2002. 1Methylcyclopropene: a review. Biology and Technology. vol. 28, pp. 1-25.
Darliah, D. T., S. Sunarjatin, dan I. Kurnia. 1994. Pengaruh lamanya perendaman dan konsentrasi IBA terhadap pertumbuhan vegetatif stek mawar (Rosa multiflora). Buletin Penelitian Tanaman Hias 2(2):43-49.

Dole J. M. and H.F Wilkins. 2005. Floriculture: principle and species, 2nd edition. New Jersey Jersey: Pearson Prentice Hall.

Franklin P.G., R.B. Pearce, L. Roger., and Mitchell. 1991. Fisiologi Tanaman Budidaya (Penerjemah Herawati S. dan Subiyanto) Jakarta : Penerbit UI Press.

Humphries, E.C. dan A.W. Wheeler. 1963. Annu. Rev. Plant Physiol.

Parker, R. 1999. Introduction to Plant ScienceRevised. Delmar Publishers. NewYork. 752 p.

Salisbury, F. B. dan C. W Ross. 1995. Fisiologi Tumbuhan. Jilid 3. Penerbit: ITB, Bandung.

Setyadjit, C.J Daryl, E.I Donald, and D.H Simons. 2011. 1-MCP (1-Methyl Cyclopropene) Protected grevillea 'Sylvia' inflorescenses against exogenous ethylene. Prosiding Seminar Nasional Teknologi Pascapanen Pertanian : 293-303.

Setyadjit, E. Sukasih dan A.W. Permana. 2012. Aplikasi 1-MCP dapat memperpanjang umur segar komoditas hortikultura. Bul. Teknol. Pascapanen Pert. Vol 8(1)hal 28-34.

Sisler E.C. and M. Serek. 1999. Compounds controlling the ethylene receptor. Bulletin Botanica Academia Sinica. 40: 1-7.

Suryowinoto S.M. 1997. Flora Eksotika, Tanaman Hias Berbunga. Yogyakarta : Penerbit Kanisius.

Widiastoety, D. 1995. Pengaruh intensitas cahaya terhadap pertumbuhan anggrek Dendrobium. Jurnal Hortikultura 4 (5) : 72-75.

Winarno F.G dan M. Aman. 1981. Fisiologi Lepas Panen. Institut Pertanian Bogor. Sastra Hudaya. Jakarta Pusat. 